\title{
A science-technology-society approach to teacher education for the foundation phase: Students' empiricist views
}

\begin{abstract}
Teacher education for South African foundation phase education requires student teachers to be prepared for teaching science concepts in an integrated programme in a learning area known as life skills. This study examined the challenges faced by university teachers of foundation phase student teachers in the development of science modules/ courses. The national curriculum for this subject aims to strengthen learner awareness of social relationships, technological processes and elementary science (DBE 2011a). We developed an integrated numeracy, science and technology module for foundation phase student teachers, based on the science-technology-society (STS) approach to teaching science concepts. Students' understanding of science concepts was assessed, using a project method in which they solved a problem derived from children's literature. Then students' views of this integrated approach to teaching science concepts were gathered. The negative views of the foundation phase student teachers towards the integrated STS approach was thought to indicate an empiricist view of the nature of science that could impede their future teaching.
\end{abstract}

Keywords: Foundation phase, science teacher education, science-technology-society, project method, nature of science

Lyn Kok, University of Zululand. Email: KokE@unizulu.ac.za

Rika van Schoor, University of the Free State.Email:vschoorj@ufs.ac.za

South African Journal of Childhood Education | 2014 4(1): 95-110 | ISSN: 2223-7674 |๑ UJ

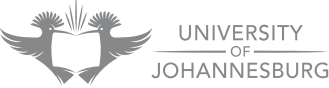




\section{Introduction}

In this study the object of inquiry was pre-service teachers' knowledge of and views about an integrated pedagogy for science teaching in the first years of school. Some South African research suggests that South African student teachers need to be better educated to teach the curriculum effectively, and that large numbers of teachers in the country have insufficient content knowledge and limited effective teaching strategies (Fleisch 2008:123). Sibaya and Sibaya (2008:86), for example, found that newly qualified teachers from University of Zululand did not feel equipped for the demands of teaching. Adler, Moletsane, Pournara, Taylor and Thorne (2009:39) reported a notable absence of research on primary mathematics and science teacher education:

We do not know enough about the kind and quantity of domain knowledge primary teachers need, and in what ways such knowledge is effectively developed - and international literature is also lacking in this area... Hence a first component of a research agenda for mathematics and science teacher education is to examine the practices of teacher education itself, attending to the ... breadth and depth of domain knowledge, subject content and pedagogy and how ... these play out.

Fakudze (2004:277) observed that teachers, especially in non-Western settings, need pre-service and in-service programmes with instructional strategies to help them present science in ways that take into account the learners' social and cultural backgrounds. Because foundation phase teacher education requires preparing student teachers in South Africa to teach science concepts in an integrated life skills programme, this study was motivated to examine the challenges faced in developing science teacher education modules for the preparation of these future teachers.

\section{Background of the study}

The purpose of South Africa's Bachelor of Education degree (grades R-3) is to develop qualified classroom teachers who can demonstrate focused knowledge and skills in teaching a particular phase or subject (DHET 2011). The country's foundation phase teachers have to teach a life skills programme, which integrates many traditional subjects and includes science and the technological process. The Curriculum and Assessment Policy Statement (CAPS) for this subject area in the foundation phase aims to strengthen learner awareness of social relationships, technological processes and elementary science (DBE 2011a). By implication, science teacher educators of foundation phase student teachers are required to prepare their students with the pedagogical content knowledge (PCK) to teach science in an integrated manner.

The aim of the study on which we report in this article, was to investigate how science concepts can be learnt by way of an integrated STS approach, and the views of student teachers about learning science concepts with this approach was also investigated. 


\section{Views of the nature of science: Implications for science teaching}

Adler et al (2009: 33) recommend that research in teacher education focus on the specific demands of teaching when there is an epistemological shift from science as product to science as process, with emphasis on investigation and the societal context of science. How teachers view science has an impact on whether they teach it as product or process.

Tsai (2006:364) defines the traditionally empiricist perspective on science as the assumption

that scientific knowledge is a discovery of an objective reality external to ourselves and discovered by observing, experimenting or application of a universal scientific method.

This view can generate two dangers according to Tsai (2006:365). First, a pedagogical danger of rote learning of facts, methods and problem-solving procedures and, second, that science is considered as "infallible and a body of facts". Teacher education that emphasizes the empiricist perspective of science would not prepare future teachers for teaching science as a process or the societal context of science.

Lemke (2001: 300) observed that it falsifies the nature of science (NOS) to teach concepts outside their social, economic, historical, and technological contexts, and, as Tsai (2006:363) makes clear, constructivist views (epistemologies) of science emphasise the progressive development of scientific understanding and recognition of technological, contextual and cultural factors that may have an effect on understanding and developing science concepts. The South African foundation phase curriculum implies the need for such a constructivist approach, as its key science process skills are listed as inquiry skills (DBE 2011a) and, Charlesworth and Lind (2013:67) point out inquiry-oriented instruction "reflects the constructivist model of learning".

According to Tsai (2006: 364), the international literature suggests that many teachers still hold empiricist-aligned views about the NOS. Research is not available for the views of South African foundation phase teachers or student teachers, even though such views affect the approach they take when teaching science in their classrooms. Although our research did not specifically examine the student teachers' views on the NOS, we argue that these can be deduced from their views on being taught science concepts by means of the STS approach.

\section{Science concept development and assessment during design and technology teaching}

Science concepts constitute part of the knowledge needed for teaching design and technology (D\&T). Rauscher (2010:85) observes that although technology education is perceived simplistically as applied science, it is in fact a cognitive system comprising a separate body of technological knowledge. Although an important source of knowledge for technology, science is one of several areas of relevant 
knowledge-generating activities. The D\&T classroom requires learners to apply science concepts, but Sidawi (2009:285) finds that such application can be difficult. To succeed, they need conceptual understanding of science concepts and the ability to recognise the abstract rules that apply to new situations. For such learning of science concepts to occur, Sidawi (2009:283) suggests that teaching, learning and assessment of these concepts take place within a specific context.

Children's understanding of science concepts is based on their range of experiences and interactions, and on the development of concepts' that help to explain the phenomena. Situated cognition theory defines learning as the knowledge and skills obtained in contexts that reflect the ways in which knowledge and skills are used in real life. Genuine understanding comes from the situations in which learning occurs. As children construct meaning from their own experiences, they often reach an incomplete understanding, known as an alternative concept. Through exposure to increasing sets of experiences, and through the interactions of social learning, they may start to develop concepts that relate more closely to the scientifically accepted view (Campbell 2013:27).

Besides conceptual knowledge, learners also need procedural knowledge. Teaching science through D\&T means that the design task provides the context for applying science knowledge, which in turn provides part of the content needed for performing the design task (Sidawi 2009:285). Doppelt, Mehalik and Schunn (2008:71) compared science concept development, using design-based learning and scripted inquiry. They found that middle school learners had superior performance in terms of knowledge gain, engagement and retention if taught science concepts through a design-based rather than a scripted inquiry approach. Cajas (2001:718) admits that clarifying which ideas about technology are relevant to science education has been difficult, and that researchers need to investigate further how technological ideas and skills are learned and how they can be best taught. Oxman (1999:113) says that the simplest model of cognitive activity during the stages of the design process is a problem specification, solution type and resultant form or designed product. She cautions that measuring learning by assessing only the designed product does not include a learning increment, and she presents various models of design learning that represent improved cognitive reasoning. Based on varying methods of assessment, she could record observations of changes that occurred in the students' thinking about design, their growing skill in dealing with the complexities of design thinking, and the dynamic progress of their performance. Cajas (2001:722) uses a bridge project to illustrate teaching issues that had been raised when introducing a conception of technology that goes beyond artifact into understanding of technological ideas such as failure (of structures due to forces), properties of materials, selection of materials, and understanding trade-offs and constraints. Cajas (2001:726) and Campbell Ginns and Stein (2002:36), agree that the curriculum and understanding it thoroughly is vital to underpin teachers' approach to technology education in the classroom.

We argue that new goals of assessment in science focus on the link to the broader social context, but that practice has not yet caught up. The inadequacy of research 
on appropriate assessment strategies for science education is especially important for South African learners, who continue to perform poorly on standardized written tests for mathematics and science. Gopal and Stears (2007) note that these tests cannot know the experienced curriculum of classrooms. Constable (1993) further argues that there will be no standardization of D\&T assessment until there is consensus about what a good D\&T activity is, and highlights the challenge of standardising the assessment of D\&T tasks for seven year olds.

In this study the designed product was assessed using a rubric with criteria based on science concept application during the design process.

\section{The process approach to science and technology education in the foundation phase}

In helping children to construct knowledge, the teacher can prepare a child's science experience in many ways, for instance, through a process skills approach, guided discovery learning, inquiry learning, interactive, problem-based learning and a project approach (Campbell 2013:60). Two types of process skills are suggested by the Curriculum and Assessment Policy Statement Life Skills Foundation Phase policy document (DBE 2011a), namely the inquiry process and the technological process. In using a process skills approach, a teacher helps children to develop science knowledge while developing skills and processes to be able to undertake their own investigations (Campbell 2013:60). Examples of science teaching for young children as a process of inquiry are given by Abruscato (2012), Charlesworth (1988), Morris (2004), Kousaleos Martin and Rogers (1988) and Campbell, Froschl and Sprung, (1986). These authors advocate the planning of science activities which develop the natural curiosity of young learners. Careful planning allows for the investigation of science concepts while developing science process skills. Once the teachers initiate the inquiry, young learners are encouraged to do further investigations independently. This study, on the other hand, focuses on learning science concepts while following the technological process.

Teachers responsible for technology education (which includes teaching the process of technology) in South African schools generally lack formal training in this field, and have neither the relevant content knowledge, nor the methodology to teach the design process (Rauscher 2012:19). Our view is that they require high quality curriculum materials and professional development courses to improve their content and pedagogical knowledge. They also need opportunities to interact with other teachers. Research on learning at schools and the knowledge of teachers should be at the heart of the science/technology interaction (Cajas 2001:726). Investigating teacher education, Rauscher (2010:87) reported on the extent to which knowledge-generating activities were applied by Bachelor of Education students in two technology education modules at the University of Pretoria, but did not make it clear whether these student teachers were being taught for a specific school phase. A study of technology education teacher training programmes at several South African universities by Poole, Reitsma and Mentz (2013) describes the knowledge, skills and 
values that such teachers need and identifies the shortcomings of these programmes. They recommend the inclusion of opportunities to practice technology subject skills and teaching processes to develop appropriate teaching strategies by technology teachers. During the present study, the inclusion of a project as an assessment task ensured the application of technological skills and processes.

International research on teaching the technological process in early childhood education (ECE) settings found that existing curricula offered little support for teachers to figure out the nature, aims and pedagogical means of ECE technology education. Siu and Lam (2005), Ebach, Endepohls-Ulpe, Ikonen, Rasinen, Stahl-von Zabern and Virtanen (2009) and Chatoney, Endepohls-Ulpe and Turja (2009) all note that teacher education focus is needed for this kind of technology education to improve. There is, however, a useful body of knowledge for developing foundation phase student teacher curricula. Milne's (2013) comprehensive literature review highlights D\&T challenges faced by young learners entering formal education, and the need for curricula to be evaluated for their effectiveness in providing teachers with the content and pedagogical knowledge to apply the technological process (as well as the scientific inquiry process) in foundation phase classrooms. The present study describes the views of foundation phase student teachers on teaching science and technology processes in an integrated module.

\section{Integration of science and technology processes}

Whereas the foundation phase education policy for life skills does not overtly advocate an integrated approach, it implies an integration of science, technology and social issues in stating, as a specific aim, that the life skills programme should expose learners to a range of knowledge, skills and values that strengthen their awareness of social relationships, technological processes and elementary science (DBE 2011a). The document also advocates a constructivist approach which the teaching of the scientific and technological processes would ensure. Tsai (2000:203) is encouraged that recent practice of STS instruction has shown potential for explicating the constructivist epistemology of science for learners.

Children's literature can provide a starting point for integrating social issues within science and technology, and an opportunity for teachers to turn everyday events found in storybooks into meaningful curricula for young learners (Freeman, Feeney \& Moravcik, 2011; Waks, 1993). Understanding the problem in the story leads young learners to design and make the solutions. The nature of D\&T is that these solutions are open-ended (Campbell et al 2002:37), and the teacher would therefore facilitate the building of different products.

It is because there are so few trained teachers of technology education in South Africa, and because the process approach to teaching science and technology is specified in the foundation phase life skills curriculum, that the present B.Ed. (FP) module was developed, implemented, assessed and the students' views of the integration of the two processes was sought. 


\section{Method}

This is a case study of an integrated STS numeracy, science and technology module in a teacher education programme for the teaching of science concepts. It was conducted as a quasi-experimental intervention during which 44 groups, of four or fewer students each, completed a project. They had to follow the technological process to design and make a strengthened, insulated house for the 'Country Mouse', which, on returning from a visit to his cousin in town, found that he no longer had a house (Brett 2013). Design folios and model houses were assessed using a rubric with criteria for competence, as well as a checklist.

The project scores were statistically analysed with SPSS Statistics (version 21). A t-test for independent groups was used to determine whether there was a significant difference among the groups that scored above and those that scored below the mean. The result was used to decide whether this project could be used to distinguish between how student groups understood and could apply science concepts during the technological approach and those that could not.

At the end of the intervention, student views on the teaching of science concepts, using the STS approach, were obtained through individual interviews and focus group discussions, which were recorded and then transcribed. Data from the interviews and focus groups were organised into themes. The tool for analysing the qualitative data was typological analysis as described by Cohen, Manion and Morrison (2007:473).

\section{Sampling}

The sample comprised 168 second year foundation phase B.Ed. students from a ruralbased South African university. The 168 students completed the project in groups of 4 or fewer and all student groups' results for the design and making process were used for statistical analysis. Purposive sampling was utilised to select six students to interview individually. A further two focus groups of five students each further discussed their experience during the intervention. They were selected from the oldest and youngest in the class.

\section{Assessment rubric and checklist for the design and make of the model house}

The rubric and checklist are included (table 1 and table 2) to show how the design and the heuristic of the stages of the technological process were used to assess the application of the following concepts: Area, volume, and material properties such as insulation and strength. The science process skills of measurement and communication (through drawings and modelling) were also assessed. The group scores generated by the rubric and checklist were analysed statistically to decide whether the STS approach used did result in student teachers' ability to apply science concepts during the technological process. 
Table 1: Rubric for the assessment of the group work design of the mouse house (Total of 38 marks)

\begin{tabular}{|c|c|c|c|c|}
\hline$\frac{\pi}{\frac{\pi}{2}}$ & 1 & 2 & 3 & 4 \\
\hline 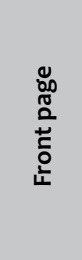 & $\begin{array}{l}\text { A front page is } \\
\text { provided with } \\
\text { some decorations, } \\
\text { but it is untidy or } \\
\text { without colour. }\end{array}$ & $\begin{array}{l}\text { A front page is } \\
\text { provided that } \\
\text { is relevant for } \\
\text { the design of a } \\
\text { mouse house, } \\
\text { but little colour } \\
\text { is evident and it } \\
\text { is not very neat. }\end{array}$ & $\begin{array}{l}\text { A front page is provided } \\
\text { with relevant diagrams } \\
\text { for the design of a } \\
\text { mouse house. The } \\
\text { diagrams are beautifully } \\
\text { coloured. }\end{array}$ & \\
\hline 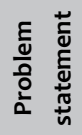 & $\begin{array}{l}\text { Problem } \\
\text { statement given, } \\
\text { but not relevant to } \\
\text { mouse house. }\end{array}$ & $\begin{array}{l}\text { Relevant } \\
\text { problem } \\
\text { statement } \\
\text { given. }\end{array}$ & & \\
\hline $\begin{array}{l}\frac{4}{\frac{0}{2}} \\
\frac{0}{5} \\
\frac{000}{y} \\
\frac{0}{0}\end{array}$ & $\begin{array}{l}\text { Design brief given, } \\
\text { but not relevant to } \\
\text { making of mouse } \\
\text { house. }\end{array}$ & $\begin{array}{l}\text { Design brief } \\
\text { given, which } \\
\text { is relevant to } \\
\text { making a mouse } \\
\text { house. }\end{array}$ & & \\
\hline 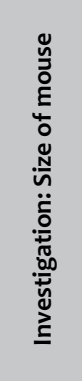 & $\begin{array}{l}\text { Size of a mouse } \\
\text { is given, but } \\
\text { no evidence } \\
\text { of information } \\
\text { source given. Or } \\
\text { information given } \\
\text { is incomplete. }\end{array}$ & $\begin{array}{l}\text { Length of } \\
\text { average mouse } \\
\text { is given, with } \\
\text { evidence, but } \\
\text { no reference for } \\
\text { the information } \\
\text { source. }\end{array}$ & $\begin{array}{l}\text { Evidence of information } \\
\text { found from a reliable } \\
\text { source is given, with the } \\
\text { correct reference. Only } \\
\text { relevant information } \\
\text { is given for the length, } \\
\text { breadth and height of } \\
\text { a specific species of } \\
\text { mouse. }\end{array}$ & $\begin{array}{l}\text { Evidence of } \\
\text { information found } \\
\text { from a reliable source } \\
\text { is given, with the } \\
\text { correct reference. } \\
\text { Only relevant } \\
\text { information is given } \\
\text { for the length, breadth } \\
\text { and height of a specific } \\
\text { species of mouse. } \\
\text { Information is given as } \\
\text { a scaled diagram. }\end{array}$ \\
\hline 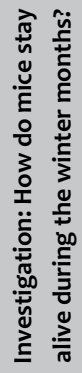 & $\begin{array}{l}\text { Information } \\
\text { given, but without } \\
\text { evidence or } \\
\text { reference. }\end{array}$ & $\begin{array}{l}\text { Information is } \\
\text { given with a } \\
\text { reference or } \\
\text { evidence. }\end{array}$ & $\begin{array}{l}\text { Information is given } \\
\text { with evidence and a } \\
\text { reference. Only relevant } \\
\text { information is given. }\end{array}$ & $\begin{array}{l}\text { Evidence and } \\
\text { reference for more } \\
\text { than one source is } \\
\text { given. Only relevant } \\
\text { information is given. }\end{array}$ \\
\hline
\end{tabular}




\begin{tabular}{|c|c|c|c|c|}
\hline 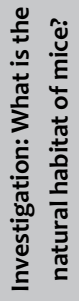 & $\begin{array}{l}\text { Information } \\
\text { given, but without } \\
\text { evidence or } \\
\text { reference. }\end{array}$ & $\begin{array}{l}\text { Information is } \\
\text { given with a } \\
\text { reference or } \\
\text { evidence. }\end{array}$ & $\begin{array}{l}\text { Information is given } \\
\text { with evidence and a } \\
\text { reference. Only relevant } \\
\text { information is given. }\end{array}$ & $\begin{array}{l}\text { Evidence and } \\
\text { reference for more } \\
\text { than one source is } \\
\text { given. Only relevant } \\
\text { information is given. }\end{array}$ \\
\hline 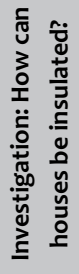 & $\begin{array}{l}\text { Information } \\
\text { given, but without } \\
\text { evidence or } \\
\text { reference. }\end{array}$ & $\begin{array}{l}\text { Information is } \\
\text { given with a } \\
\text { reference or } \\
\text { evidence. }\end{array}$ & $\begin{array}{l}\text { Information is given } \\
\text { with evidence and a } \\
\text { reference. Only relevant } \\
\text { information is given. }\end{array}$ & $\begin{array}{l}\text { Evidence and } \\
\text { reference for more } \\
\text { than one source are } \\
\text { given. Only relevant } \\
\text { information is given. }\end{array}$ \\
\hline 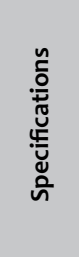 & $\begin{array}{l}\text { Only one relevant } \\
\text { specification is } \\
\text { given. }\end{array}$ & $\begin{array}{l}\text { Only two } \\
\text { relevant } \\
\text { specifications } \\
\text { are given. }\end{array}$ & $\begin{array}{l}\text { Specifications correctly } \\
\text { given for size of house, } \\
\text { insulating materials and } \\
\text { features such as a door } \\
\text { and window. }\end{array}$ & $\begin{array}{l}\text { Specifications } \\
\text { correctly given for size } \\
\text { of house, insulating } \\
\text { materials and features } \\
\text { such as a door and } \\
\text { window. One other } \\
\text { relevant specification } \\
\text { is given. }\end{array}$ \\
\hline 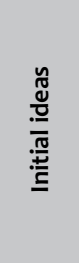 & $\begin{array}{l}\text { Only one initial } \\
\text { idea drawing } \\
\text { is submitted in } \\
\text { the design folio } \\
\text { or only one is } \\
\text { drawn correctly } \\
\text { according to scale. }\end{array}$ & $\begin{array}{l}\text { At least two of } \\
\text { the initial idea } \\
\text { drawings are } \\
\text { correctly drawn } \\
\text { to scale. }\end{array}$ & $\begin{array}{l}\text { All four members have } \\
\text { submitted correctly } \\
\text { scaled free-hand } \\
\text { isometric drawings } \\
\text { for a mouse house. } \\
\text { Not all drawings show } \\
\text { dimensions according to } \\
\text { specifications. }\end{array}$ & $\begin{array}{l}\text { All four members have } \\
\text { submitted correctly } \\
\text { scaled free-hand } \\
\text { isometric drawings } \\
\text { for a mouse house. } \\
\text { All drawings show } \\
\text { dimensions according } \\
\text { to the specifications. }\end{array}$ \\
\hline 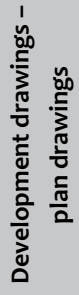 & $\begin{array}{l}\text { The plan drawing } \\
\text { is not drawn } \\
\text { to scale or } \\
\text { specifications. }\end{array}$ & $\begin{array}{l}\text { The plan } \\
\text { drawing is } \\
\text { drawn either } \\
\text { to scale or to } \\
\text { specifications. }\end{array}$ & $\begin{array}{l}\text { The plan drawing is } \\
\text { correctly drawn to } \\
\text { scale and according to } \\
\text { specifications. }\end{array}$ & $\begin{array}{l}\text { The plan drawing is } \\
\text { correctly drawn to } \\
\text { scale and according } \\
\text { to specifications. } \\
\text { Features such as the } \\
\text { door and window are } \\
\text { correctly shown on } \\
\text { the plan. }\end{array}$ \\
\hline 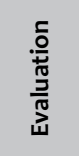 & $\begin{array}{l}\text { Questions are } \\
\text { noted from the } \\
\text { specifications. }\end{array}$ & $\begin{array}{l}\text { Questions are } \\
\text { answered in a } \\
\text { checklist. }\end{array}$ & $\begin{array}{l}\text { Questions are answered } \\
\text { honestly with some } \\
\text { notes on how the } \\
\text { mouse house can be } \\
\text { improved. }\end{array}$ & \\
\hline
\end{tabular}


Table 2: Checklist for the assessment of the group work mouse house

\begin{tabular}{|l|l|l|}
\hline \multicolumn{1}{|c|}{ Criteria } & Yes (1) & No (0) \\
\hline Is the house fairly sturdily joined together? & & \\
\hline Is the cardboard neatly cut? & & \\
\hline Are the sides of the house mostly vertical? & & \\
\hline Is the length of the house correct according to the plan drawing? & & \\
\hline Is the width of the house correct according to the plan drawing? & & \\
\hline Is the height correct according to the specifications? & & \\
\hline Does the house have a door? & & \\
\hline Is the door the size as stipulated on the plan drawing? & & \\
\hline Does the house have a window? & & \\
\hline Is the size of the window as stipulated on the plan drawing? & & \\
\hline Is there a form of insulation for the floor? & & \\
\hline Is there a form of insulation for the walls? & & \\
\hline Is there a form of insulation for the roof? & & \\
\hline Is the overall appearance of the house mostly neat? & & \\
\hline Is the house neatly decorated? & & \\
\hline Total (out of 15) & & \\
\hline
\end{tabular}

\section{Findings and discussion}

The findings of the study are presented in two parts. Firstly, the assessment of the design folio and models using the rubric and checklist (tables 1-2) and, secondly, the students' views on the learning of science concepts by means of the STS approach.

\section{Analysis of assessment scores for the 'mouse house' project}

Figures 1-3 illustrate the design and making of a mouse house by one of the groups, showing the application of science process skills during the project.

The results of the t-test for independent groups (table 3 ) show a significant difference between the high and low scoring groups $(p<0.000)$. It indicates that they performed differently in the application of science concepts such as insulation and strengthening in the design and making of their houses; measurement and understanding area and volume in their drawings (figures 1-3); communicating their understanding of dimensions and scale in 2D and 3D drawings (figures 2-3); and making accurately scaled models from their design drawings (figure 1). The t-test results confirmed our views that the project method for assessment of science concept application would distinguish between student groups who could apply science concepts during the solving of a technological problem and those who could not. They also suggest that slightly more than half of the student groups (25/44) seemed to benefit from the integrated STS teaching approach. 
Figure 1: Photograph of one of the group-work-project mouse houses

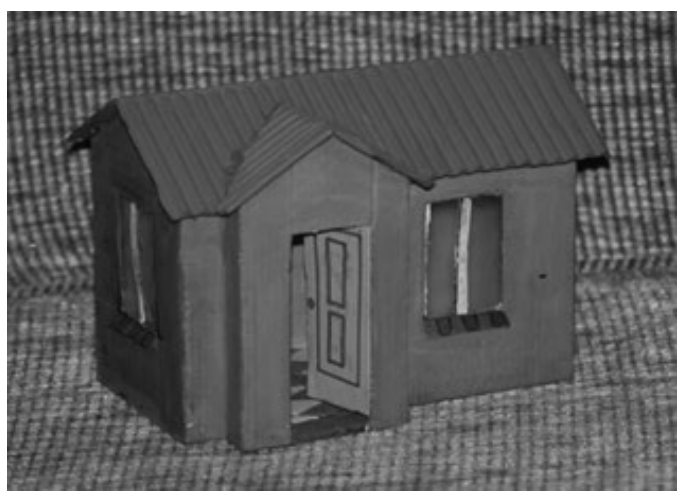

Figure 2: The three-dimensional drawing of the group's mouse house

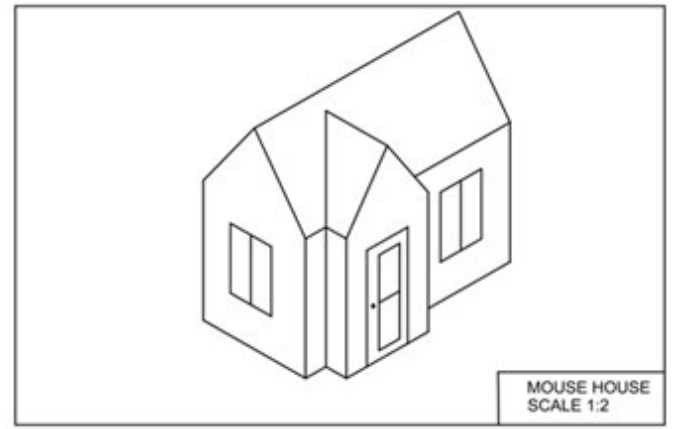

Figure 3: The plan drawing for the group's mouse house

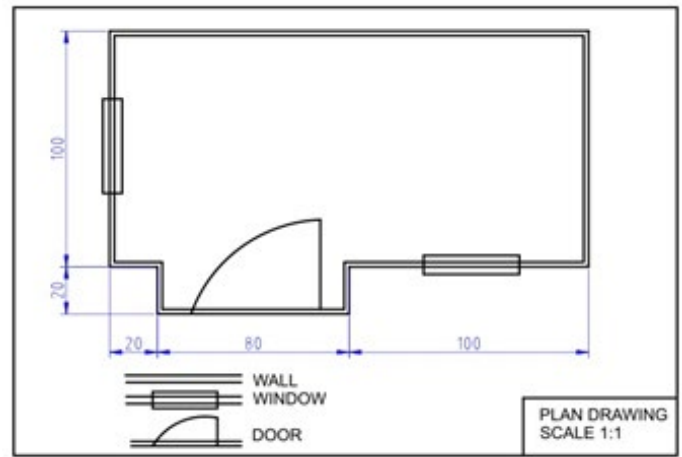


Table 3: Difference between high scoring and low scoring groups

\begin{tabular}{|c|c|c|c|c|c|c|c|}
\hline \multirow[b]{2}{*}{ Result group } & \multirow[b]{2}{*}{$\mathbf{N}$} & \multirow[b]{2}{*}{ Mean } & \multirow{2}{*}{$\begin{array}{l}\text { Std. } \\
\text { dev. }\end{array}$} & \multirow{2}{*}{$\begin{array}{l}\text { Std. error } \\
\text { of the mean }\end{array}$} & \multicolumn{3}{|c|}{ t-test for Equality of Means } \\
\hline & & & & & $\mathbf{T}$ & Df & $\begin{array}{c}\text { Sig. } \\
\text { (2-tailed) }\end{array}$ \\
\hline Above mean & 25 & 67 & 6.746 & 1.349 & 9.021 & 42 & .000 \\
\hline Below mean & 19 & 49 & 6.644 & 1.524 & 9.040 & 39.206 & .000 \\
\hline
\end{tabular}

\section{Analysis of student interviews on the use of the STS project as a teaching and learning approach}

Three themes stood out from the transcriptions of the individual interviews and the focus group discussions: The use of the technological process; the need for practical classes; and the learning of science concepts through the use of the technological process.

First, all the students in the individual interviews could recall the stages of the technological process, such as researching the size of the mouse, drawing the plan and insulating and decorating the house.

Highlighting the need for research, student D commented: "We had to find the size of the mouse so we could make the house big enough", and student B added: "We really had to do research - if we do not research we would talk generally and not always be correct". Student B also highlighted the association of the project with real life ("learning about insulation has relevance for my own home") and the broader implications of project planning with the words: "We realised that you had to have a plan to build a house".

Second, the need for practical classes was highlighted by student C, who suggested that the lecturer "must continue presenting demonstrations, because we learn by seeing", but added that it "would be good for students to do practical demonstrations". All the participants felt that the schools they themselves had attended as learners had lacked the equipment to conduct science investigations, and only one felt that she had learnt to measure during her schooling (student $\mathrm{H}$ ).

Third, all the students interviewed individually and during the focus group discussions felt that they would prefer to have science taught separately from technology. Student B felt that it was necessary to know when a scientific concept is being dealt with and suggested that: "The lecturer should make it more obvious when dealing with a science concept like energy transfer". Student F said: "I am swimming in a sea of confusion". Student I preferred to integrate science and technology herself, and student $\mathrm{L}$ agreed, but both added that the lecturer should guide the integration. Although all participants felt that science and technology were important subjects there were definite preferences for one or the other. Student $F$ preferred technology to science because she was good at drawing. Student $G$ preferred science to technology and gave two reasons: First, “... drawing confuses me”, and second, "I am familiar with science, but not technology". These answers raised the importance of 
previous knowledge, with the ability to draw as a deciding factor for whether or not the students enjoyed technology.

\section{Implications}

Findings of this study revealed that, whereas learning of science concepts took place and students were able to apply their knowledge in designing and building a structure, they retained their empiricist view of the nature of science.

Although this study did not specifically seek the views of student teachers on the NOS, these are implied in their views on being taught with the STS approach. Teachers' views about the NOS will affect the approach taken when teaching science in their classrooms (Tsai 2006:364) and it would therefore be useful to review the module and to include ways of challenging the students' thinking about the NOS. Their existing empiricist views may have developed from their own learning of science in primary school (Tsai 2000:203). Such views can result in teaching strategies that obscure scientific meaning and go against the grain of a constructivist epistemology, which is the position advocated in the curriculum policy. Further questions arising from our findings include the following:

- How can the teacher education programmes address the issue of student teachers' empiricist views of science?

- How can student teachers be taught to plan (and implement) science concept development of foundation phase learners in their teaching in the life skills curriculum?

In reviewing and revising our module, we would now consider including 1) conditions and models of conceptual change and teaching strategies that facilitate conceptual change in young learners, and 2) inquiry-based practical classes for students to develop their understanding of science concepts, which includes an awareness of the role of social factors.

Introducing practical classes requires careful planning to ensure that students are ready to learn by way of a constructivist epistemology and concomitant teaching approach. An added benefit of practical classes would be to give the hoped-for change a greater chance of succeeding, as the students would be discussing their inquiry process and the change would happen in a social context as advocated by Lemke (2001) and Fakudze (2004).

Reviewing and revising the module in this way gives the researchers the opportunity to continue to research how science concepts are developed using the STS approach and how science concepts can be assessed during the integrated STS approach. 


\section{Conclusion}

This study found that the project method for assessing the application of science concepts to be appropriate in a specific social context of mostly rural-based students. The study succeeded in eliciting the views of students about their experience of the STS approach to learning science concepts. The method was also found to be appropriate for assessing the application of science concepts, although most students viewed the integration of science and technology as confusing and would have preferred the science concepts to be taught separately - probably due to their strong empiricist views of science as a subject. Such views held by foundation phase student teachers are likely to undermine their future teaching of science in the integrated manner suggested by the curriculum. There is a need for further research on how to change most effectively the views of students from an empiricist to a constructivist one regarding the nature of science. Based on our findings, we suggest that models of conceptual change and teaching strategies that facilitate conceptual change should be included in student teacher training through our module, as well as practical classes for students to develop their own constructivist understanding of science concepts.

\section{Acknowledgements}

We thank the Research and Innovation office of the University of Zululand for support in making the writing of this article possible, and professor P.T. Sibaya for his comments on the statistical analysis.

\section{References}

Abruscato, J. 2012. Teaching children science: A discovery approach. Boston: Allyn \& Bacon.

Adler, J., Moletsane, G., Pournara, C., Taylor, D. \& Thorne, B. 2009. Mathematics and science teacher education in South Africa: A review of research, policy and practice in times of change. African Journal of Research in Mathematics, Science and Technology Education (Special Issue), 1:28-46.

Brett, J. 2013. Town Mouse, Country Mouse. Retrieved from http://www.puffin.co.uk/ nf/Book/CoverlmagePopup/0,,9780723272823,00.html (accessed 12 July 2014).

Cajas, F. 2001. The science/technology interaction: Implications for science literacy. Journal of Research in Science Teaching, 38(7):715-729.

Campbell, C. 2013. Teaching approaches. In Campbell, C. \& Jobling, W. (eds.). Science in EarlyChildhood.Retrievedfromhttp://dx.doi.org/10.1017/CBO978113919197007.005 (accessed 12 November 2013).

Campbell, P.B., Froschl, M. and Sprung, B. 1986. What will happen if ... Young children and the scientific method. Day Care and Early Education, Summer:28-35. 
Campbell, J., Ginns, I.S. \& Stein, S.J. 2002. Implications of missed opportunities for learning and assessment in design and technology education. Teaching and Teacher Education, 18(1):35-49.

Charlesworth, R. 1988. Integrating math with science and social studies: A unit example. Day Care and Early Education, Summer:28-31

Charlesworth, R. \& Lind, K.K. 2013. Maths and science for young children. ( $7^{\text {th }}$ edition). Australia: Cengage Learning.

Chatoney, M., Endepohls-Ulpe, M. and Turja, L. 2009. A conceptual framework for developing the curriculum and delivery of technology education in early childhood. International Journal of Technology and Design Education, 19(1):353-365.

Cohen, L., Manion, L. \& Morrison, K. 2007. Research methods in education. ( $6^{\text {th }}$ edition). London: Routledge.

Constable, H. 1993. A note on the first technology assessment tasks at Key Stage 1. International Journal of Design and Technology Education, 3(3):31-36.

DBE (Department of Basic Education) 2011a. Curriculum and Assessment Policy Statement Life Skills Foundation Phase. Retrieved from http://www.education. gov.za/LinkClick.aspx?fileticket=a7A1AT1Rrns= (accessed 12 July 2014).

DBE (Department of Basic Education) 2011b. Curriculum and Assessment Policy Statement Mathematics Foundation Phase. Retrieved from http://www. education.gov.za/LinkClick.aspx?fileticket=ehGEpQZXz7M\%3d\&tabid $=671 \& \mathrm{~m}$ $\underline{i d=1880}$ (accessed 12 July 2014).

DHET (Department of Higher Education and Training). 2011. The minimum requirements for teacher education qualifications. Pretoria.

Doppelt, Y., Mehalik, M.M. \& Schunn, C.D. 2008. Middle-school science through design-based learning versus scripted inquiry: Better overall science concept learning and equity gap reduction. Journal of Engineering Education, January:71-82.

Ebach, J., Endepohls-Ulpe, M., Ikonen, P., Rasinen, A., Stahl-von Zabern, J. and Virtanen, S.2009. Technology education for children in primary schools in Finland and Germany: Different school systems, similar problems and how to overcome them. International Journal of Technology and Design Education, 19(1):367-379.

Fakudze, C.G. 2004. Learning of science concepts within a traditional socio-cultural environment. South African Journal of Education, 24(4):270-277.

Fleisch, B. 2008. Primary education in crisis: Why South African schoolchildren underachieve in reading and mathematics. Cape Town: Juta.

Freeman, N.K., Feeney, S. \& Moravcik, E. 2011. Enjoying a good story: Why we use children's literature when teaching adults. Early Childhood Education Journal, 39(1):1-5.

Gopal, N. \& Stears, M. 2007. An alternative approach to assessing science competencies. African Journal of Research in Mathematics, Science and Technology Education, 11(2):15-24. 
Kousaleos, S., Martin Jr., R.E. \& Rogers, D.L. 1988. Encouraging science through playful discovery. Day Care and Early Education, Fall:20-23.

Lemke J.L. 2001. Articulating communities: Sociocultural perspectives on science education. Journal of Research in Science Teaching, 38(3):296-316.

Milne, L. 2013. Nurturing the designerly thinking and design capabilities of five-year-olds: Technology in the new entrant classroom. International Journal of Technology and Design Education, 23(2):349-360.

Morris, M. 2004. Interacting in science in early childhood: A "project" approach. Teaching Science, 50(3):11-14.

Oxman, R. 1999. Educating the designerly thinker. Design Studies, 20(2):105-122.

Poole, J., Reitsma, G. \& Mentz, E. 2013. Technology teacher training in South Africa: Shortcomings and recommendations. International Journal of Technology and Design Education, 23(2):455-472.

Rauscher, W. 2010. Knowledge-generating activities on which technology education students draw when they design and make artefacts. African Journal of Research in Mathematics, Science and Technology Education, 14(1):85-98.

Rauscher, W. 2012. How project-based learning manifests itself in technology education textbooks. African Journal of Research in Mathematics, Science and Technology Education, 16(1):18-31.

Sibaya, D. \& Sibaya, P. 2008. Novice educators' perceptions of the teacher education programme proposed by the Norms and Standards for Educators. Perspectives in Education, 26(4):86-100.

Sidawi, M.M. 2009. Teaching science through designing technology. International Journal of Technology and Design Education, 19(1):269-287.

Siu, K.W.M. \& Lam, M.S. 2005. Early childhood technology education: A sociocultural perspective. Early Childhood Education Journal, 32(6):353-358.

Tsai, C.C. 2000. Relationships between student scientific epistemological beliefs and perceptions of constructivist learning environments. Educational Research, 42(2):193-205.

Tsai, C.C. 2006. Reinterpreting and reconstructing science: Teachers' view changes toward the nature of science by courses of science education. Teaching and Teacher Education, 22(1):363-375.

Waks, L.J. 1993. STS as an academic field and a social movement. Technology in Society, 15(1):399-408. 